\title{
Nutritional Pattern And Healing Of Perineum Wound On Postpartum Period
}

\author{
Heni Frilasari ${ }^{1}$, Noer Saudah ${ }^{2}$, Veryudha Eka Prameswari ${ }^{3}$, Yeni Nur Azizah ${ }^{4}$, \\ Byba Melda Suhita ${ }^{5}$ \\ ${ }^{1,2,3,4}$ Sekolah Tinggi Ilmu Kesehatan Bina Sehat PPNI Indonesia \\ ${ }^{5}$ Institut Ilmu Kesehatan STRADA Indonesia \\ Coresponding author: noersaudah15@gmail.com
}

\begin{abstract}
Background: Postpartum period was the return of uterine implants such as before pregnancy which takes 6 weeks after born. Good nutrition patterns would speed healing wound perineum. The high nutritional content of calories, protein, fluids, and vitamins needed for speed up perineal wound closure.

Purpose: This study aimed to determine the relationship of postnatal maternal nutritional patterns with the healing of perineal wounds in Puri community health center Mojokerto.

Methods: Analytical research design with Cross-Sectional. The population used postpartum mothers with perineal injuries. The sampling technique was through consecutive. The sample size was 90 respondents. The independent variable was nutrition pattern and the dependent variable was perineal wound healing. The instrument used was a questionnaire sheet postpartum maternal nutrition pattern and observation sheets for perineal wound healing.

Results: The results showed 56 respondents $(63.3 \%)$ had good nutrition patterns and good perineal wound healing, 27 respondents $(30 \%)$ had poor nutrition patterns and moderate perineal wound healing, as many as 7 respondents $(6.7 \%)$ had nutritional patterns less and bad perineal wound healing. Chi-Square statistical test results showed $\rho(0,000)<\alpha 0.05$.

Conclusion: It could concluded that there was a relationship between the nutritional pattern of the puerperal mother with the healing of perineal wounds. High caloric, protein, fluid and mineral intake and vitamins in the puerperium mother will accelerate the process of new cell regeneration so that the puerperal perineal wound heals faster. Postpartum mothers are expected to maintain a nutritional pattern for healing the perineal wound and not do certain food restrictions during the puerperium.
\end{abstract}

Keywords: Nutritional Pattern, Perineal Wound, Postpartum, Puerperal 


\section{BACKGROUND}

The postpartum period begins after the placenta is born and ends when uterine utensils return to their pre-pregnancy state. The postpartum period lasts for approximately 6-8 weeks (Wahyuningsih, 2019). During the puerperium, wounds on the birth canal are usually called the perineal wounds. The perineal wound is a wound in the area between the two thighs, between the vulva and the anus caused by rupture or episiotomy wound at the time of delivery (Syaiful, 2019).

Perineal wound healing if no infection occurs will heal within 6-7 days (Syaiful, 2019). The speed of healing of perineal wounds is influenced by the basic needs of postpartum mothers about nutrition. During the puerperium, high nutrition is needed with enough calories, protein, fluids, and vitamins. Nutritional factors will affect the healing of birth canal wounds. Sari (2014) explained the nutritional status will affect wound healing. In some patients, a decrease in protein content will affect wound healing.

The phenomenon at the Puri Community Health centers in Mojokerto Regency shows that postpartum mothers experience delays in healing perineal wounds due to the habit of abstaining from food and avoiding fishy-smelling foods such as eggs and fish. Also obtained is the healing of the perineal wounds for more than 7 days.

Perineal wounds in Indonesia are experienced by $75 \%$ of vaginal delivery mothers (Boyle, 2009). In 2015 it was found that out of 1,951 spontaneous vaginal births, $59 \%$ of mothers received perineal sutures (29\% due to episiotomy and $30 \%$ due to spontaneous tears) (Kemenkes, 2015). Based on PWS-KIA Mojokerto in 2017 reports were reported on postpartum mothers totaling 16,413 people and in 2018 there were 13,673 people (Dinkes Mojokerto, 2015). Documentation of perineal wounds in Mojokerto district has not been officially documented. Based on a preliminary study conducted on December 12, 2018, at Puri Health Center Mojokerto through interviews and observations on 5 postpartum mothers who control 7 days with perineal wounds, 2 people said they did not consume meat, eggs, chicken and the amount of drinking 1 large bottle per day. The results of the observation of perineal wounds appear to be still reddish in color. 3 people said they ate meat, eggs, chicken, salted fish but did not limit the amount of drinking. Observation results of perineal wounds appear dry.

The results of this study are in line with research from (Suryati, 2013) showing that with good nutritional status, $74,2 \%$ of respondents experienced normal wound healing. This can be seen from the observation that the perineal wound appears dry and tight, there are also no signs of infection such as pain, heat, swelling, redness, and dysfunction. While patients with malnourished status experienced an abnormal wound healing process of $77,8 \%$.

The impact of abstinence behavior during puerperium is a lack of nutrients so that healing of wounds will heal for a longer period of time even infection can arise. Especially in postpartum women certainly, need nutritious food to restore the condition to accelerate the healing of perineal wounds and the lactation process. If the nutrition of postpartum mothers can be fulfilled properly then the perineal suture can heal quickly and the mother can carry out daily activities (Saidah, 2011).

Based on the description above, the researcher was interested in further investigating the Relationship of the Nutrient Patterns of Postpartum Mothers with the Healing of Perineal Wounds at Puri Health Center Mojokerto. 


\section{Objective}

The purpose of this study was to analyze the relationship between the nutritional pattern of postpartum mothers and the healing of perineal wounds at Puri Health Center Mojokerto.

\section{Methods}

This study used a type of analytic correlation study with a cross-sectional approach. The population in this study was postpartum mothers with perineal wounds at Puri Health Center Mojokerto. The sampling technique used the consecutive sampling technique The sample size was 90 respondents. Independent variables of postpartum maternal nutrition pattern and the dependent variable of perineal wound healing. Retrieval of postpartum Mother Nutrition Pattern data used a questionnaire sheet and Perineal Wound Healing using an observation sheet. The time of the study was conducted on February 20 - April 21, 2019. Analyze data used the Chi Squares statistical test.

Respondents were certain to receive an explanation of this research and asked to fill out and sign an agreement with the guarantee of confidentiality of information to unauthorized parties.

The participants were assured that their engagement was voluntary, and that anonymity, privacy, and confidentiality of the data were guaranteed. Furthermore, they were informed about the purpose and the method of the study before signing a written informed consent.

\section{Results}

\section{A. General Data}

Table 1. Frequency Distribution of Respondents of Postpartum Mothers at Puri Health Center Mojokerto

\begin{tabular}{lcc}
\hline \multicolumn{1}{c}{$\begin{array}{c}\text { Characteristics of } \\
\text { Respondents }\end{array}$} & F & $(\%)$ \\
\hline Age & & \\
$<20$ years & 9 & 10 \\
20-25 years & 30 & 33.3 \\
26-30 years & 33 & 36.7 \\
31-40 years & 18 & 20
\end{tabular}

\begin{tabular}{lcc} 
Work & & \\
Entrepreneur & 3 & 3.3 \\
Private & 27 & 30 \\
Civil servants & 3 & 3.3 \\
Housewife & 57 & 63.3 \\
Education & & \\
Elementary & 18 & 20 \\
school & 69 & 76.7 \\
High school & 3 & 3.3 \\
College & $\mathbf{9 0}$ & $\mathbf{1 0 0}$ \\
\hline Total & &
\end{tabular}

Source: Primary Data, 2019

Based on table 1 shows the characteristics of respondents based on age most respondents aged 26-30 years as many as 33 respondents (36.7\%). Shows that the majority of respondents have jobs as housewives as many as 57 respondents $(63.3 \%)$. Shows that the majority of respondents have the last education is high school as many as 69 respondents $(76.7 \%)$. 


\section{B. Special Data}

This data illustrates specific data about the relationship of nutritional patterns of postpartum mothers with the healing of perineal wounds at Puri Health Center Mojokerto

Table 2. Frequency of Respondents Distribution Based on Nutrition Patterns of Post Partum Mothers at Puri Health Center Mojokerto

\begin{tabular}{|c|c|c|c|}
\hline No. & Criteria of Nutrition Pattern & $\mathbf{F}$ & $(\%)$ \\
\hline 1. & Good & 57 & 63.3 \\
\hline 2. & Less & 23 & 36.7 \\
\hline & Total & 90 & 100 \\
\hline
\end{tabular}

Source: Primary Data, 2019

Based on table 2 shows that the majority of respondents had good nutrition pattern criteria, namely as many as 57 respondents $(63,3 \%)$.

Table 3. Frequency Distribution of Respondents Based on Healing Perineal Wounds at Puri Health Center Mojokerto

\begin{tabular}{ccccc} 
No & \multicolumn{2}{c}{ Criteria Healing Wound } & F & $(\boldsymbol{\%})$ \\
\hline 1. & Good & 57 & 63.3 \\
2. & Medium & 27 & 30 \\
3. & Bad & 6 & 6.7 \\
\hline \multicolumn{2}{r}{} & Total & $\mathbf{9 0}$ & $\mathbf{1 0 0}$ \\
\hline
\end{tabular}

Source: Primary Data, 2019

Based on table 3 shows that the majority of respondents had good healing perineal wounds criteria, namely as many as 57 respondents $(63.3 \%)$.

\begin{tabular}{|c|c|c|c|c|c|c|c|c|}
\hline \multirow{3}{*}{$\begin{array}{l}\text { The Nutrition } \\
\text { Patterns }\end{array}$} & \multicolumn{6}{|c|}{ Healing of Perineal Wounds } & \multirow{2}{*}{\multicolumn{2}{|c|}{ Total }} \\
\hline & \multicolumn{2}{|c|}{ Good } & \multicolumn{2}{|c|}{ Medium } & \multicolumn{2}{|c|}{ Bad } & & \\
\hline & $\mathrm{F}$ & $\%$ & $\mathrm{~F}$ & $\%$ & $F$ & $\%$ & $\mathrm{~F}$ & $\%$ \\
\hline Good & 57 & 100 & 0 & 0 & 0 & 0 & 57 & 100 \\
\hline Less & 0 & 0 & 9 & 82 & 6 & 6.7 & 11 & 100 \\
\hline Total & 57 & 63 & 27 & 30 & 6 & 6.7 & 90 & 100 \\
\hline
\end{tabular}

Table 4.

Relationship

between

Postpartum

Maternal Nutrition

Patterns with

Healing Perineal

Wounds at Puri

Health Center Mojokerto

Source: Primary Data, 2019 


\section{Journal Of Nursing Practice}

http://thejnp.org

ISSN: 2614-3488 (print); 2614-3496 (online)

Vol.3 No.2. April 2020. Page.172-180

Based on table 4 the results of cross-tabulation showed that of the 90 respondents that the respondents with good nutritional patterns were found to have perineal wound healing as many as 57 respondents $(63.3 \%)$. While the respondents with less nutritional patterns were found to have moderate perineal wound healing as many as 9 respondents $(30 \%)$ and poor perineal wound healing as many as 6 respondents $(6.7 \%)$.

Based on statistical tests that have been determined in data analysis using the ChiSquare test technique obtained a significant level of 0,000 with $\alpha<0,05$ so that there is a relationship between nutritional patterns of postpartum mothers with the healing of perineal wounds at Puri Health Center Mojokerto.

\section{DISCUSSION}

\section{The Nutrition Pattern of Postpartum Mother}

Based on table 2 shows that the majority of respondents have good nutritional pattern criteria as many as 57 respondents $(63.3 \%)$.

The pattern of nutrition that is formed is very closely related to one's eating habits. In general, the factors that influence the formation of nutritional patterns are factors of knowledge, prejudice, habits, preferences, and economics (Damayanti, 2015).

Based on table 1 shows that most of the last education of respondents is high school, which is as many as 69 respondents (76.7\%). Education in this case usually associated with knowledge will affect the selection of food ingredients and fulfillment of nutritional needs. The higher the education of a person, the easier it is to receive information so that the more knowledge he has, the less education will inhibit one's attitude towards the values introduced (Notoatmodjo, 2010). One example of the principle possessed by someone with low education is usually the important thing to consider so that the portion of food sources of carbohydrates is more than other foodstuffs. Conversely, higher education people have a tendency to choose food sources of protein and will try to balance with other nutritional needs.

Almost all respondents have good nutritional pattern criteria due to the high level of education that the respondents have. The level of education affects the level of knowledge of a person, the higher the level of education, the higher the level of knowledge about health, one of which is the pattern of nutrition. If a good pattern of nutrition will affect the level of health, one of them is the healing of the perineal wound in the postpartum mother.

\section{Healing of Perineal Wounds}

Based on table 3 shows that most respondents have good wound healing criteria as many as 57 respondents $(63.3 \%)$.

Perineal wound healing is beginning to improve perineal wounds with the formation of new tissue that covers the perineal wound within a period of 6-7 postpartum days. The act of cleaning the vulva can provide an opportunity to carry out a careful inspection of the perineum area. Infection can occur is very unlikely if the perineal wound is treated properly (Bahiyatun, 2009).

Based on Table 3, it shows that the respondents have poor wound healing criteria, which are as many as 9 respondents $(6.7 \%)$. As a result of improper perineal treatment can result in the condition of the perineum that is affected by the lock a become moist so it is very supportive of the development of bacteria that can cause infection in the perineum (Puspitasari, 2011). Inadequate treatment of perineal wounds will result in 
inflammation or infection (Saidah, 2015). Personal hygiene factors that are not able to slow healing, this can cause the presence of foreign objects such as dust and germs. The infection causes an increase in inflammation and necrosis which inhibits wound healing.

\section{Relationship between Nutrition Patterns of Postpartum Mothers and the Healing of Perineal Wounds at Puri Health Center Mojokerto}

Based on table 4 the results of cross-tabulation showed that of the 30 respondents that the respondents with good nutritional patterns were found to have perineal wound healing as many as 57 respondents (63.3\%). While the respondents with less nutritional patterns were found to have moderate perineal wound healing as many as 9 respondents (30\%) and poor perineal wound healing as many as 2 respondents $(6,7 \%)$. Based on the results of statistical tests using Chi-Square, there was a significant level of 0,000 with $\alpha<0,05$ so that there was a relationship between the nutritional pattern of postpartum mothers and the healing of perineal wounds at Puri Health Center Mojokerto.

The pattern of nutrition is a variety of information that provides an overview of the type and amount of food consumed every day by one person and is a characteristic for a particular group of people (Sulistyoningsih, 2011). Nutrition patterns affect the healing of perineal wounds in postpartum mothers. During the puerperium, quality nutrition is needed with enough calories, protein, fluids, and vitamins. Nutrition is needed by the body for metabolic purposes. Nutritional needs during the puerperium, especially if breastfeeding will increase by $25 \%$ because it is useful for the healing process because after childbirth. All that will increase three times the usual needs. Foods consumed are useful for activities, metabolism, reserves in the body, the process of producing breast milk (Wahyuningsih, 2019).

Based on Table 3, it shows that the respondents have poor wound healing criteria, which are as many as 9 respondents $(6.7 \%)$. As a result of improper perineal treatment can result in the condition of the perineum that is affected by the lack a become moist so it is very supportive of the development of bacteria that can cause infection in the perineum (Puspitasari, 2011). Inadequate treatment of perineal wounds will result in inflammation or infection (Onyango AW. et.all, 2011). During the puerperium microorganisms such as bacteria, viruses and fungi are very easy to find. Therefore, the maintenance of perineal wounds during the puerperium period must be properly guarded (Sofian, 2011). Personal hygiene factors that are not able to slow healing, this can cause the presence of foreign objects such as dust and germs. Identification of the type of bacteria as a cause of genital infection in women, especially intimate organs, must be washed properly and dried, no ointment is needed. Most perineal wounds occur because postpartum mothers are afraid to clean them so that the wound area is buried with dirt and postpartum blood which is a medium for germ growth. Moreover, ointments that contain oil, dirt will be buried and the base of the wound covered with fat so it cannot dry. If perineal wound care is done correctly, the wound will heal quickly, and vice versa. During the period of puerperal infection is very wide, it must be maintained the cleanliness of the wound because the germs like the moist area and will also disrupt the wasting of the uterus (involution) so that the uterus will remain enlarged. Perineal wound healing is due to the mother's knowledge of nutritional needs during the puerperium period is not following the rules of the fulfillment of good and balanced nutrition so that the wound is not dry. 


\section{CONCLUSION}

Based on the results of the study, it was shown that there was a relationship between the nutritional pattern of postpartum mothers and the healing of perineal wounds at Puri Health Center Mojokerto. The perineal wound healing process requires adequate nutrition, nutritional requirements for the puerperium are determined by a pattern of good nutrition by postpartum mothers. Good protein intake in postpartum mothers will improve the new cell regeneration process so that the perineal wound of the postpartum mother tends to heal faster. Mothers with good nutritional patterns will accelerate the formation of scar tissue and accelerate the formation of fibrin threads so that the wounds heal soon.

\section{ACKNOWLEDGMENTS}

Researchers would like to thank the chairman of Institute Health Science Bina Sehat PPNI for providing research funding facilities. Thank you also goes to The researchers would like to thank the chairman of the PPNI Health Development Institute for Health Sciences for providing research funding facilities. Thank you also to respondents who participated in the research

\section{CONFLICTS OF INTEREST}

There is no conflict of interest in this study. 


\section{Journal Of Nursing Practice}

http://thejnp.org

ISSN: 2614-3488 (print); 2614-3496 (online)

Vol.3 No.2. April 2020. Page.172-180

\section{REFERENCES}

Bahiyatun, S. P. (2009). Buku Ajar Asuhan Kebidanan Nifas Normal. Jakarta; EGC.

Boyle, M. (2009). Pemulihan Luka Seri Praktik Kebidanan. Jakarta; EGC.

Damayanti, I. P., Risa Pitriani, S. S. T., Kes, M., Yulrina Ardhiyanti, S. K. M., \& Kes, M. (2015). Panduan Lengkap Keterampilan Dasar Kebidanan II. Deepublish.

Kemenkes, R. I. (2015). Profil Kesehatan Indonesia 2015. Jakarta: Kementerian Kesehatan Republik Indonesia.

Mojokerto, D. K. (2015). Profil Kesehatan Dinas Kesehatan Kabupaten Mojokerto. AKB dan AKI.

Noer, S., Agus, S., \& Adriani, M. (2015). Model of Independency Mother in Caring for Preterm Infant based on Experiential Learning Care (ELC). International Journal of Evaluation and Research in Education, 4(4), 200-206.

Notoatmodjo, S. (2010). Ilmu perilaku kesehatan. Jakarta: Rineka Cipta.

Onyango, A. W., Nommsen- Rivers, L., Siyam, A., Borghi, E., de Onis, M., Garza, C., ... \& Araújo, C. L. (2011). Post- partum weight change patterns in the WHO Multicentre Growth Reference Study. Maternal \& child nutrition, 7(3), 228-240. https://doi.org/10.1111/j.1740-8709.2010.00295.x

Puspitasari, H. A., \& Sumarsih, T. (2011). Faktor-faktor yang mempengaruhi Penyembuhan Luka Post Operasi Sectio Caesarea (SC). Jurnal Ilmiah Kesehatan Keperawatan, 7(1).

Saidah, N. (2011). Perilaku Pantang Makanan Pada Ibu Nifas Di Polindes Desa Lebak Rejo Kecamatan Purwodadi Kabupaten Pasuruan. Hospital Majapahit (JURNAL ILMIAH KESEHATAN POLITEKNIK KESEHATAN MAJAPAHIT MOJOKERTO), 3(2).

SARI, E. P. (2014). HUBUNGAN ANTARA PANTANG MAKANAN PADA MASA NIFAS DENGAN PENYEMBUHAN LUKA PERINEUM DI WILAYAH KERJA PUSKESMAS JATIWATES KECAMATAN TEMBELANG KABUPATEN JOMBANG. KTI D3 KEBIDANAN.

Syaiful, Y., Ns, S. K., Kep, M., Fatmawati, L., ST, S., \& Kes, M. (2019). Asuhan Keperawatan Kehamilan. Jakad Media Publishing.

Sofian, A. (2011). Sinopsis obstetri: Obstetri fisiologi, obstetri patologi. Jakarta: EGC.

Sulistyoningsih, H. (2011). Gizi Untuk Kesehatan Ibu dan Anak. Yogyakarta: Graha Ilmu. 
Suryati, Y., Kusyati, E., \& Hastuti, W. (2013). Hubungan Tingkat Pengetahuan Ibu Nifas Tentang Perawatan Luka Perineum Dan Status Gizi Dengan Proses Penyembuhan Luka. Jurnal Manajemen Keperawatan, 1(1).

Wahyuningsih, S. (2019). Buku Ajar Asuhan Keperawatan Post Partum Dilengkapi Dengan Panduan Persiapan Praktikum Mahasiswa Keperawatan. Deepublish. 